\title{
A foszfordinamika jellemzői trágyázási tartamkísérletek talajaiban
}

\author{
SÁRDI Katalin \\ Pannon Egyetem, Georgikon Kar, Növénytermesztéstani és \\ Talajtani Tanszék, Keszthely
}

\section{Bevezetés}

Közismert, hogy a tápanyag-gazdálkodásban a foszfor kiemelt szerepet játszik. A foszfor a növények, az állatok és az ember számára egyaránt létfontosságú tápelem, ugyanakkor a foszfor tápanyagellátás nem csupán a talaj növények számára felvehető P-tartalmát növelheti, hanem egy kritikus koncentráció fölött környezeti kockázattal járhat. A hatékonyságot a környezetkímélő tápanyag-gazdálkodásban növelni kell, a mütrágya hatóanyag érvényesülés javításán és a környezet terhelését okozó veszteségek csökkentésével. A környezetkímélő mezőgazdasági tevékenység (ezen belül a tápanyag-gazdálkodás) törvényi szabályozását szolgálja hazánkban az 1990-es évektöl több hatályos törvény, ill. kormány-rendelet, amelyek a természeti erőforrások védelmére irányulnak. A hatékony és korszerü tápanyaggazdálkodáshoz ezek ismerete ma már nélkülözhetetlen (FÜLEKY \& SÁRDI, 2014).

$\mathrm{Az}$ elmúlt évtizedekben a foszfor környezeti kockázatainak pontosabb megismerését célzó nemzetközileg koordinált törekvések egyre nagyobb szerepet töltenek be, amelyet jól tükröz, pl. az OECD "Environmental Indicators for Agriculture" címü összefoglaló kiadványa, melyben a rendszeres talaj- és vízvizsgálatokat, az üzemi (farm gate balance) és az országos foszfor tápelem mérlegek számítását egyaránt szükségesnek ítélik (OECD Proceedings, 1999).

Az OECD elöírások szerint, 2004 óta Magyarországnak is közölnie kell a mezögazdasági területek környezetvédelmi P-mérleg adatait $\left(\mathrm{kg} \mathrm{P}_{2} \mathrm{O}_{5} \cdot \mathrm{ha}^{-1}\right)$. Az 1990-es évektől a mérleg minden évben negatív. A 2010-es csapadékos évben a nagyobb termésátlagok miatt az átlagos $\mathrm{P}_{2} \mathrm{O}_{5}$ érték $9 \mathrm{~kg} \cdot \mathrm{ha}^{-1}$-al kevesebb volt. (Összehasonlításként: az 1980-as érték $+41,0 \mathrm{~kg} \cdot \mathrm{ha}^{-1}, 2000$-ben $-7,0 \mathrm{~kg} \cdot \mathrm{ha}^{-1}$ volt).

\section{A talaj foszfor-ellátottságának megállapitása}

Bár a növények számára a fö foszfor-forrásnak a szervetlen P-formákat tekintik, a labilis, ezért könnyen átalakuló szerves P-formák mineralizációjára vonatkozóan bebizonyosodott, hogy azok a különbözö termékenységü talajokon fontos Pforrások.

Postai cím: SÁRDI KATALIN, Pannon Egyetem, Georgikon Kar, 8360 Keszthely, Deák F.

u. 16.E-mail: sardi@georgikon.hu 
Az elmúlt évtizedekben világszerte nagyszámú kísérletet végeztek a talajok foszfor-ellátottságának biológiai módszerü megállapítására. Több szerző véleménye szerint a talaj P-ellátottságának és a foszfor utóhatásának jellemzésére a növényi Pfelvétel alkalmasabb, mint a termés mennyisége. Általában a tenyészedénykísérleteket tartják előnyösebbnek e célra, mivel szabadföldi körülmények közt több tényező ellenőrizhetetlen vagy nem ismert (QUÉMENER, 1979; RAHMAN, 2012).

A hagyományos talaj P-meghatározási módszerek környezetvédelmi célú alkalmazása iránt növekszik az érdeklődés. Ennek oka, hogy összefüggést találtak a különböző módszerekkel kivonható talaj P-tartalom és a felszíni elfolyással, lemosódással távozó víz oldott szervetlen ortofoszfát (oldott reaktív-P), biológiailag felvehető foszfor-, valamint összes foszfortartalma között.

A talaj P-teszt értékek és a felszíni, ill. felszín alatti vizekbe jutó foszfor menynyisége közötti kapcsolathoz hasonlóan a talajokban meghatározható az a kritikus P-telítettségi szint, amely fölött ugrásszerúen megnövekszik a mezőgazdasági eredetű foszfor környezeti kockázata (CSATHÓ et al., 2003; OszTOICS et al., 2004).

\section{A kivonószerek jelentősége}

A talajok tápanyag-állapotának jellemzésére világszerte számos kivonószert alkalmaznak: erős és gyenge savakat, ill. ezek sóit, lúgos kémhatású oldatokat, valamint vizet. Ezek egy része csak bizonyos talajkémhatásnál alkalmazható, pl. a Bray 1 és a Bray 2 savanyú talajokra, míg az Olsen-módszer elsősorban meszes talajokra. Vannak olyan kivonószerek, amelyek különböző talajkémhatásnál is jó hatásfokúak a felvehető foszfor mennyiségének megállapítására, pl. a Mehlich-3, valamint a hazánkban elterjedt AL- (ammónium laktátos) módszer.

A talajok könnyen oldható P-tartalmának és az egyes foszfát-frakciók (pl. a Ca-, Al- és a Fe-foszfátok) meghatározására alkalmazott kivonószereket hazánkban FÜLEKY (1976) hasonlította össze eltérő tulajdonságú talajokra.

További nehézség a könnyen oldható tápelemtartalom heterogenitása, amely az alkalmazott agrotechnika, föként a trágyázás (adag és mód) függvényében számottevően befolyásolja az eredményeket. Évtizedekkel ezelőtt hívták fel erre a figyelmet, pl. JACKSON (1958), aki szerint a mintavételből származó hiba háromnégyszer, vagy akár nagyságrenddel is nagyobb lehet, mint a laboratóriumi analitikai hiba.

Az MTA TAKI műtrágyázási tartamkísérletében SARKADI és munkatársai számoltak be a talaj heterogenitásából eredő problémákról, amelyek az ellátottság és a mütrágya-hatások kapcsolatában jelennek meg (SARKADI et al., 1986).

A talaj P-teszt módszerekkel szemben támasztott követelmények, hogy jól reprodukálhatók, gyorsan és olcsón elvégezhetők és rutinvizsgálatokra is alkalmasak legyenek.

\section{Kisérleteink}

Az Országos Mütrágyázási Tartamkísérletek (OMTK) és más tartamkísérletek (Szentgyörgyvölgy és Keszthely) talajait felhasználva, tenyészedény- és inkubáci- 
ós-kísérletekben vizsgáltuk a talajok foszfordinamikájának mennyiségi viszonyait, foszfor-retencióját és -szolgáltató képességét. Az elvégzett vizsgálatok eredményei lehetőséget adtak a mütrágyával kijuttatott foszfor utóhatásának, valamint az oldhatósági viszonyok megváltozásának tanulmányozására is.

\section{Anyag és módszer}

Kísérleti talajok: a keszthelyi Ramann-féle barna erdőtalajon, ill. a szentgyörgyvölgyi pszeudoglejes barna erdőtalajon beállított trágyázási tartamkísérletek talajmintái. A 10 év (1963-1973) intenzív, növekvő adagú feltöltő foszfortrágyázás (BALÁZS \& NÉMETH, 2002) eredményeként a talajokban három növekvő foszforellátottsági szint jött létre. A 10 évig folytatott trágyázás beszüntetése után, 30 év elteltével talajmintákat vettünk. A talajok legfontosabb kémiai tulajdonságait az 1 . táblázatban foglaltuk össze.

\section{1. táblázat}

A kísérleti talajok föbb jellemzői

\begin{tabular}{|c|c|c|c|c|c|c|}
\hline \multirow{2}{*}{$\begin{array}{c}\text { (1) } \\
\text { Tartam } \\
\text { P-szint }\end{array}$} & \multirow{2}{*}{$\begin{array}{c}\mathrm{pH} \\
\left(\mathrm{H}_{2} \mathrm{O}\right)\end{array}$} & \multirow{2}{*}{$\underset{(\mathrm{KCl})}{\mathrm{pH}}$} & Olsen-P & AL-P & AL-K & $\mathrm{N}_{\min }$ \\
\hline & & & \multicolumn{4}{|c|}{$\mathrm{mg} \cdot \mathrm{kg}^{-1}$} \\
\hline \multicolumn{7}{|c|}{ Keszthely (Orthic Eutrochrept) } \\
\hline $\mathrm{P}_{0}$ & 6,88 & 5,93 & 14,53 & 19,4 & 114,8 & 31,8 \\
\hline $\mathrm{P}_{1}$ & 6,96 & 5,98 & 10,93 & 14,33 & 117,4 & 19,8 \\
\hline $\mathrm{P}_{2}$ & 7,05 & 6,14 & 16,63 & 25,81 & 126,6 & 17,2 \\
\hline \multicolumn{7}{|c|}{ Szentgyörgyvölgy (Typic Albaqualf) } \\
\hline $\mathrm{P}_{0}$ & 6,72 & 6,14 & 22,96 & 44,77 & 112,8 & 10,7 \\
\hline $\mathrm{P}_{1}$ & 6,54 & 5,93 & 39,16 & 66,76 & 117,4 & 12,6 \\
\hline $\mathrm{P}_{2}$ & 6,60 & 6,16 & 40,62 & 69,30 & 105,4 & 12,1 \\
\hline
\end{tabular}

Megjegyzés: A talaj P- és K-tartalma $\mathrm{P}_{2} \mathrm{O}_{5}$ és $\mathrm{K}_{2} \mathrm{O}$-ra vonatkozik

A trágyázási tartamkísérletben 10 év alatt kijuttatott összes hatóanyag mennyisége:
$\mathrm{P}_{0}$ trágyázási szint (kontroll):
$0 \mathrm{~kg} \mathrm{P}_{2} \mathrm{O}_{5} \cdot \mathrm{ha}^{-1}$,
$\mathrm{P}_{1}$ trágyázási szint:
$1032 \mathrm{~kg} \mathrm{P}_{2} \mathrm{O}_{5} \cdot \mathrm{ha}^{-1}$
$\mathrm{P}_{2}$ trágyázás szint:
$1986 \mathrm{~kg} \mathrm{P}_{2} \mathrm{O}_{5} \cdot \mathrm{ha}^{-1}$

A foszforvegyületek oldhatósági viszonyainak alakulását inkubációs tenyészedény-kísérletekben tanulmányoztuk.

A szabadföldi kísérletek talajmintáival két eltérő hőmérsékleten $\left(10\right.$ és $\left.40^{\circ} \mathrm{C}\right) 2$, ill. 60 napig folytattuk a kísérleteket, melyekben a tenyészedény-kísérletekkel azonos P-kezeléseket alkalmaztunk. A frissen adott kezelések: 0, 100, 500 és $1000 \mathrm{mg}$ $\mathrm{P}_{2} \mathrm{O}_{5} \cdot \mathrm{kg}^{-1}$. Az inkubációt MIM LP-123/1 típusú termosztátban folytattuk, $100 \mathrm{~g}$ talajmintával, üveg-edényekben. A talajt 70\%-os vízkapacitás értéken tartottuk. 
A kísérletek lebontásakor három eltérő tulajdonságú kivonószerrel meghatároztuk a talajminták felvehető foszfortartalmát. A vízoldható-P koncentrációját a módosított Murphy-módszerrel (MURPHY-RILEY, 1962), az Olsen által ajánlott kivonószerrel (OLSEN \& SOMMERS, 1982), valamint az AL-oldható P-tartalmat az EGNER és munkatársai (1960) által javasolt módszertan szerint mértük. A foszfortartalmat kolorimetriásan határoztuk meg.

$\mathrm{Az}$ eredmények statisztikai értékelését ANOVA analízissel és korrelációszámítással végeztük.

\section{Kísérleti eredmények és értékelésük}

Kísérletsorozatunk részeredményeit több közleményben bemutattuk (SÁRDI, 2001; SÁRDI \& CSATHÓ, 2002; SÁRDI \& CSATHÓ, 2010). Főbb eredményeinkröl a terjedelmi korlátok figyelembevételével jelen dolgozatunkban kívánunk áttekintést adni.

\section{A foszforvegyületek oldhatóságának változása}

Általánosan jellemző, hogy a foszfor utóhatása még 30 év elteltével is érvényesült, ahogy az AL, Olsen és Bray 1 kivonószerekkel meghatározott P-tartalom értékeknél is megmutatkozott. A frissen adott kezelések hatását egyértelmüen mutatták az inkubációt követő talajvizsgálatoknál kapott értékek ugrásszerü növekedései.

A kivonószerekkel mért talaj P-tartalmak (AL-, Olsen-, Bray 1-, $\mathrm{CaCl}_{2-}, \mathrm{H}_{2} \mathrm{O}$ - és FeO-P), valamint a P-szorpciós kapacitás \%-os telítettsége és az agronómiai optimumok az eltérő pufferkapacitású két talajon jóval kisebbnek bizonyultak, mint a környezeti szempontból kritikus talaj P-tartalmak, amelyeket az Olsen-P és a $\mathrm{CaCl}_{2^{-}}$ P közötti összefüggés alapján határoztunk meg (MAGYAR et al., 2002).

Megállapítottuk, hogy a három eltérő kivonószerrel meghatározott Pmennyiségek sorrendje: Vízoldható-P $<$ Olsen-P $<$ AL-P.

A hőmérséklet és az inkubációs időtartam jelentős, a legtöbb kezelésben statisztikailag igazolható különbségeket eredményezett a vízoldható-, az Olsen- és az ALP-tartalomban. A három kivonószerrel kapott eredmények között statisztikailag igazolható kapcsolatot mutattunk ki. Az eredményeket a 2. táblázatban foglaltuk össze. Az összefüggés $P=0,1 \%$ szinten igazolható volt ( $R^{2}$ értékek 0,498 és 0,985 között változtak; $\mathrm{n}=48)$. A $10{ }^{\circ} \mathrm{C}$ hömérsékleten a savas kémhatású $\mathrm{AL}$-oldattal kapott értékek jelentősen nagyobbak voltak.

Terjedelmi korlátok miatt csak a keszthelyi talajjal kapott eredményeket mutatjuk be. Eredményeink szerint a magasabb hőmérséklet kedvezett a talajban a foszfor immobilizációjának (3. táblázat). Megfigyelhető, hogy ezen a talajon az ALoldható foszfortartalom csökkenése a magas hömérsékleten a frissen kijuttatott Padagok növekedésével együtt nőtt. A vízoldható foszfor-formák csökkenése az Olsen-P és AL-P értékekhez képest jelentősebb mértékü volt, jelezve, hogy a rövid távú inkubáció alatt is jelentős az immobilizáció.

A frissen adott foszfor átlagos hasznosulását a 4. táblázat szemlélteti. 


\section{2. táblázat}

A különböző kivonószerekkel mért P-tartalom értékek közötti kapcsolat 2 és 60 napos inkubációt követően

\begin{tabular}{|c|c|c|c|c|}
\hline \multirow{2}{*}{$\begin{array}{c}(1) \\
\text { Kivonószerek }\end{array}$} & \multicolumn{2}{|l|}{$\begin{array}{c}\text { (2) } \\
\text { Inkubációs idő, } 2 \text { nap }\end{array}$} & \multicolumn{2}{|l|}{ Inkubációs idő, 60 nap } \\
\hline & $\begin{array}{c}(3) \\
\text { Egyenlet }(\mathrm{n}=48)\end{array}$ & $\mathrm{R}^{2}$ & $\begin{array}{c}(3) \\
\text { Egyenlet }(\mathrm{n}=48)\end{array}$ & $\mathrm{R}^{2}$ \\
\hline \multicolumn{5}{|c|}{ A. Az inkubáció hömérséklete, $10^{\circ} \mathrm{C}$} \\
\hline $\begin{array}{l}\text { (a) Vízoldható-P - } \\
\text { Olsen-P }\end{array}$ & $\begin{array}{c}y=-0,0016 x^{2}+1,8052 x \\
+0,2096\end{array}$ & 0,961 & $\begin{array}{c}y=-0,0057 x^{2}+3,2652 x \\
-23,1960\end{array}$ & 0,971 \\
\hline $\begin{array}{l}\text { (b) Vízoldható-P - } \\
\text { AL- P }\end{array}$ & $y=1,5617 x+18,0190$ & 0,890 & $\begin{array}{c}y=-0,0077 x^{2}+4,4979 x \\
-20,5690\end{array}$ & 0,976 \\
\hline Olsen-P - AL-P & $y=1,1141 x+10,3570$ & 0,851 & $\begin{array}{c}y=-0,0007 x^{2}+1,6864 x \\
-1,2249\end{array}$ & 0,985 \\
\hline \multicolumn{5}{|c|}{ B. Az inkubáció hömérséklete, $40^{\circ} \mathrm{C}$} \\
\hline $\begin{array}{l}\text { (a) Vízoldható } \mathrm{P}- \\
\text { Olsen-P }\end{array}$ & $\begin{array}{c}y=-0,0064 x^{2}+3,2054 x \\
-24,0080\end{array}$ & 0,949 & $\begin{array}{c}y=-0,0154 x^{2}+4,3431 x \\
-27,0440\end{array}$ & 0,911 \\
\hline $\begin{array}{l}\text { (b) Vízoldható P - } \\
\text { AL-P }\end{array}$ & $\begin{array}{c}y=-0,0044 x^{2}+2,4854 x \\
+0,3707\end{array}$ & 0,978 & $\begin{array}{c}y=-0,0217 x^{2}+5,1630 x \\
-43,5980\end{array}$ & 0,498 \\
\hline Olsen-P - AL-P & $\begin{array}{c}y=-0,0008 x^{2}+1,0941 x \\
+8,3578\end{array}$ & 0,952 & $\begin{array}{c}y=-4 E^{-0,5} x^{2}+1,0281 x \\
-5,2070\end{array}$ & 0,537 \\
\hline
\end{tabular}

Megjegyzés: Vízoldható-P (MurPhy-RILEY, 1962); Olsen-P (OLSEN \& SOMMERS, 1982); AL-P (EGNER et al., 1960)

A hasznosulási százalékot az inkubációt követően meghatározott és a kiinduláskor mért P-tartalmak különbségéböl számítottuk. A szentgyörgyvölgyi pszeudoglejes barna erdőtalajjal végzett inkubációs kísérlet eredményei több tekintetben hasonló tendenciát mutattak a keszthelyi Ramann-féle barna erdőtalajjal kapott eredményekhez. A frissen adott kezelések hatására azonban a $\mathrm{P}_{0}$ alapszinten általában kisebb mértékü volt a P-tartalom emelkedése.

A növények által kivont foszformennyiségek tanulmányozására ezekkel a talajokkal tenyészedény-kísérleteket is végeztünk, az eredményekröl több dolgozatban számoltunk be (SÁRDI \& CSATHÓ 2002; SÁRDI et al., 2012).

Jelen dolgozatban - az eredmények megbízhatóságának alátámasztására - csak a regresszió analízis eredményeinek összevetésekor kapott szoros, szignifikáns kapcsolatot tüntetjük fel: $r=0,918\left(\mathrm{R}^{2}=0,842\right)$ (SÁRDI \& CSATHÓ, 2010). A szentgyörgyvölgyi és keszthelyi talajjal folytatott tenyészedény-kísérlet eredményei alapján lehetővé vált a savas (AL-P) és a bázikus kémhatású (Olsen-P) kivonószerrel mérhető P-tartalom közötti kapcsolat szorosságának jellemzése. Az eredményekböl látható, hogy a növényi P-felvétel és a két kivonószerrel mérhető Pmennyiség kapcsolata szoros volt $(\mathrm{P}=0,000)$, az $\mathrm{R}^{2}$ értékek 0,612 és 0,943 között változtak $(n=60)$ (5. táblázat). Az összefüggés a Ramann-féle barna erdőtalajon (Keszthely) szorosabbnak bizonyult. 
A pszeudoglejes barna erdőtalajon a növényi P-felvétel szorosabb kapcsolatot mutatott az Olsen-P mennyiségekkel, mint a Ramann-féle barna erdőtalajon (SÁRDI et al., 2009).

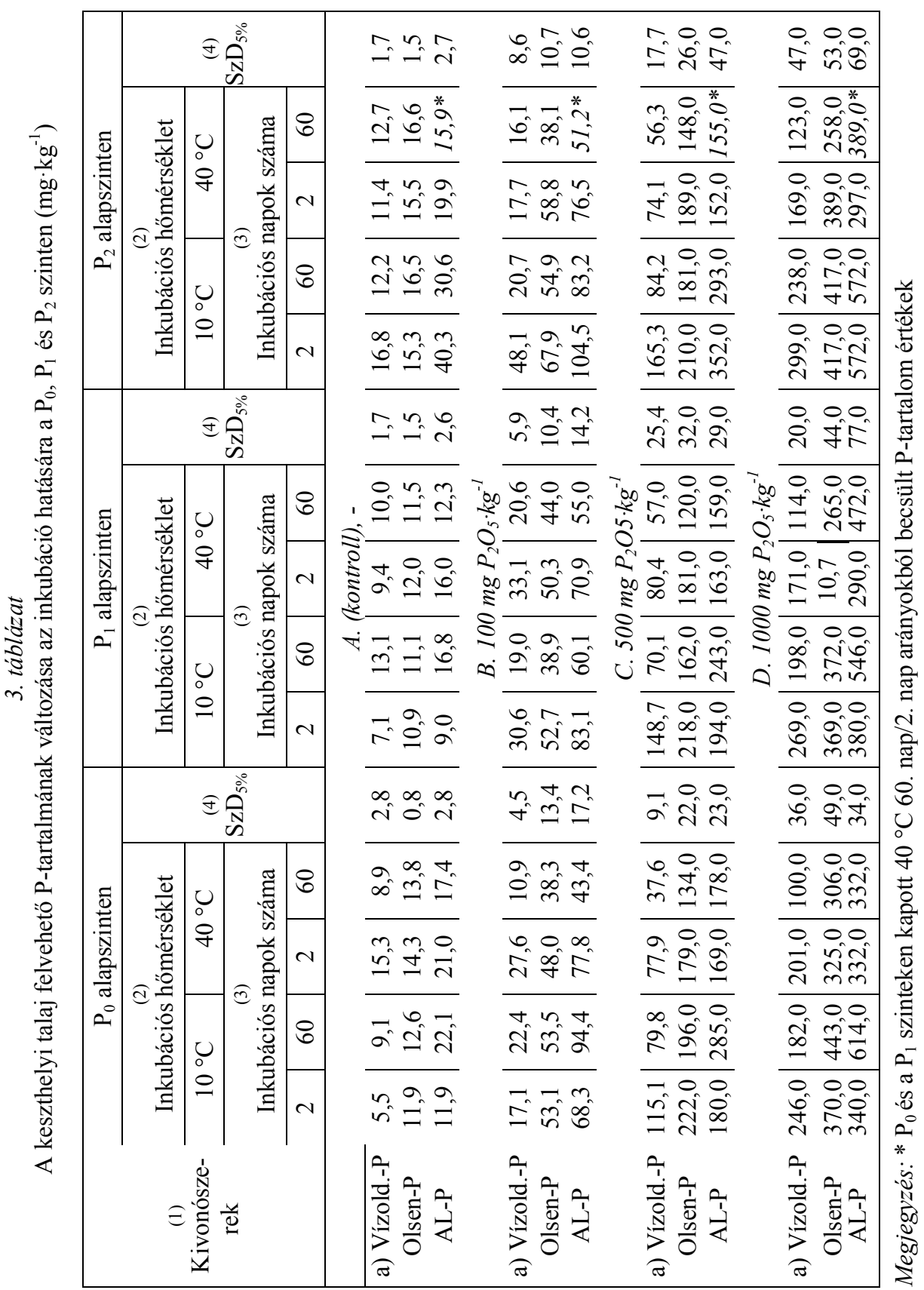


4. táblázat

A frissen adott foszfor átlagos hasznosulása (\%) a kísérleti talajokon

\begin{tabular}{|c|c|c|c|c|c|c|c|c|}
\hline \multicolumn{9}{|c|}{$\begin{array}{l}\text { (1) } \\
\text { Kísérleti helyek }\end{array}$} \\
\hline \multirow{5}{*}{$\begin{array}{c}(2) \\
\text { Tartam } \\
\text { P-szint }\end{array}$} & \multicolumn{4}{|c|}{ Keszthely } & \multicolumn{4}{|c|}{ Szentgyörgyvölgy } \\
\hline & \multicolumn{8}{|c|}{$\begin{array}{c}\text { (3) } \\
\text { Az inkubáció hőmérséklete }\end{array}$} \\
\hline & \multicolumn{2}{|c|}{$10^{\circ} \mathrm{C}$} & \multicolumn{2}{|c|}{$40^{\circ} \mathrm{C}$} & \multicolumn{2}{|c|}{$10^{\circ} \mathrm{C}$} & \multicolumn{2}{|c|}{$40^{\circ} \mathrm{C}$} \\
\hline & \multicolumn{8}{|c|}{$\begin{array}{c}\text { (4) } \\
\text { Inkubációs idő }\end{array}$} \\
\hline & 2 nap & 60 nap & 2 nap & 60 nap & 2 nap & 60 nap & 2 nap & 60 nap \\
\hline $\mathrm{P}_{0}$ & 21,5 & 19,2 & 21,1 & 9,5 & 20,2 & 15,5 & 22,4 & 12,4 \\
\hline $\mathrm{P}_{1}$ & 29,0 & 17,6 & 22,1 & 14,5 & 22,4 & 22,3 & 16,2 & 13,5 \\
\hline $\mathrm{P}_{2}$ & 37,0 & 20,4 & 16,4 & 13,3 & 27,5 & 22,8 & 17,9 & 9,4 \\
\hline
\end{tabular}

\section{5. táblázat}

A növényi P-felvétel és a két kivonószerrel mérhető felvehető P-tartalom kapcsolata $(\mathrm{n}=60)$

\begin{tabular}{|c|c|c|c|}
\hline $\begin{array}{c}\text { (1) } \\
\text { Talaj }\end{array}$ & $\begin{array}{c}\text { (2) } \\
\text { P-felvétel - AL-P }\end{array}$ & $\begin{array}{l}\text { (3) } \\
\text { P-felvétel - Olsen-P }\end{array}$ & AL-P - Olsen-P \\
\hline Keszthely & $\begin{array}{l}y=6,2927 x-15,794 \\
R^{2}=0,727\end{array}$ & $\begin{array}{l}\mathrm{y}=3,3851 \mathrm{x}-10,601 \\
\mathrm{R}^{2}=0,827\end{array}$ & $\begin{array}{l}y=0,49 x+1,5029 \\
R^{2}=0,943\end{array}$ \\
\hline $\begin{array}{l}\text { Szentgyörgy- } \\
\text { völgy }\end{array}$ & $\begin{array}{l}y=0,3967 x-63,805 \\
R^{2}=0,612\end{array}$ & $\begin{array}{l}y=3,1273 x-18,996 \\
R^{2}=0,784\end{array}$ & $\begin{array}{l}y=0,3077 x+20,606 \\
R^{2}=0,679\end{array}$ \\
\hline
\end{tabular}

\section{Következtetések}

A kísérleteinkben kapott és a fentiekben összefoglalóan bemutatott eredményeink is felhívják a figyelmet arra, hogy a talajok foszforvegyületeinek átalakulásában, hasznosulásában szerepet játszó tényezők összetett kölcsönhatások eredményeként jutnak kifejezésre. A foszfordinamika részleteinek megismerésében fontos szerepet kapnak azok a kísérletek, amelyekben kontrollált körülmények között megbízható, számszerủ adatok nyerhetők a talaj-növény rendszer foszfor tápelemforgalmára vonatkozóan. A termőhely, a talajtípusokat leginkább jellemző talajtulajdonságok szerepének további tanulmányozása szükséges a talajok foszfordinamikájának még részletesebb megértéséhez.

A hatékony és a környezetkímélő gazdálkodás követelményeinek is megfelelő foszfor tápanyag-visszapótlás továbbfejlesztéséhez ezeket az ismereteket nélkülözhetetlennek ítéljük. 


\section{Összefoglalás}

Közismert, hogy a tápanyag-gazdálkodásban a foszfor problematikája kiemelt szerepet játszik, mivel a foszfor tápanyagellátás nem csupán a talaj növények számára felvehető P-tartalmát növelheti, hanem egy kritikus koncentráció fölött környezeti kockázattal járhat. A hatékonyságot a környezetkímélő tápanyaggazdálkodásban növelni kell, a mütrágya hatóanyag érvényesülés javításán és a környezet terhelését okozó veszteségek csökkentésén keresztül. A talajok foszfordinamikájának számszerüsítése ebben kulcsszerepet tölt be.

Kísérletsorozatunkban tenyészedény- és inkubációs kísérleteket végeztünk tartamkísérletek talajaival, tanulmányoztuk a különböző talajtípusok foszfordinamikájának mennyiségi viszonyait, az egyes talajtípusok foszfor retencióját és szolgáltató képességét. Célunk volt a mütrágyával kijuttatott foszfor utóhatásának, valamint az oldhatósági viszonyok megváltozásának tanulmányozása is. Dolgozatunkban kísérletsorozatunk azon részének eredményeiröl számolunk be, amelyet Keszthelyen, Ramann-féle barna erdőtalajon (homokos vályog) és Szentgyörgyvölgyön, pszeudogleyes barna erdőtalajon (agyagos vályog) folytatott foszfortrágyázási tartamkísérletek talajaival végeztünk. A 10 évig (1963-73 között) intenzív, növekvő adagú feltöltő foszfortrágyázás eredményeként a talajokban három növekvő foszfor ellátottsági szint alakult ki. A talajmintavétel a 10 évig folytatott trágyázás beszüntetése után 30 év elteltével történt.

Megállapítottuk, hogy a foszfor utóhatása még 30 év elteltével is érvényesült, amely a vízoldható-, AL- és Olsen-P tartalomban is megmutatkozott. Inkubációs kísérleteink eredményei alapján kimutattuk, hogy a kedvező nedvességállapot a talajban alacsony hőmérsékleten elösegíti a kivonható P-tartalom rövid távú mobilizácóját, míg a magasabb hőmérséklet e formák immobilizációját fokozta.

Kulcsszavak: foszfordinamika, tartamkísérlet, inkubációs kísérlet, kivonószerek

\section{Irodalom}

BALÁZS J. \& NÉMETH I., 2002. A hatvanas évek nagyadagú foszfor-műtrágyázásának hatása és utóhatása napjainkban. In: "Környezeti ártalmak és a légzörendszer". Konferencia kiadvány. 7-17.

Csathó P., Osztoics E., SÁrdi K., SisÁk I., Magyar M. \& SzÜcs P., 2003. A mezőgazdasági területekröl a felszíni vizekbe kerülő foszfor-terhelések I. Foszforforgalmi vizsgálatok értékelése. Agrokémia és Talajtan. 52. (2-4) 473-486.

EgNER, H., RiehM, H., \& DOMINGO, W. R., 1960. Untersuchungen über die chemische Bodenanalyse als Grundlage für die Beurteilung des Nahrstoffzustandes der Böden. II.K. Lantbr. Högsz. Ann. 26. 199-215.

FÜLEKY GY., 1976. A talaj könnyen oldható P-tartalmának meghatározására használt kivonószerek vizsgálata II. Agrokémia és Talajtan. 25. 284-295.

FÜLEKY Gy. \& SÁRDI K., 2014. Tápanyag-gazdálkodás mezőgazdasági mérnököknek. Mezőgazda Kiadó. Budapest. 
JACKSON, M. L., 1958. Soil Chemical Analysis. Prentice-Hall, Inc. Eng. Cliffs N. J.

Magyar, M., Csathó, P., Debreczeni, K. \& SÁRDi, K., 2002. Correlation Among Different P-Test Methods Studied in a Network of Hungarian Long-term Field Trials. Hungarian Contributors to the $17^{\text {th }}$ International Congress of Soil Science. Agrokémia és Talajtan. 51. (1-2) 167-176.

Murphy, J. \& RiLeY, J. P., 1962. A modified single solution method for the determination of phosphate in natural waters. Anal. Chim. Acta. 27. 31-36.

OECD Proceedings, 1999. Environ. Ind. Agriculture. Vol. 2. The York Workshop.

Olsen, S. R. \& Sommers, L. E., 1982. Phosphorus. In: Methods of Soil Analysis, Part 2, Chemical and Microbiological Properties. (Ed.: PAGE, A. L.) 403-430. American Society of Agronomy. Madison. Wi.

Osztoics E., Csathó P., SÁrdi K., SisÁk I., Magyar M., Osztoics A. \& Szücs P., 2004. A mezőgazdasági területekről a felszíni vizekbe kerülő foszfor-terhelések II. A talaj foszforveszteségei, környezetvédelmi célú talaj P-vizsgálatok. Agrokémia és Talajtan. 53. (1-2) 165-180.

QÉmener, J., 1979. The Measurement of soil Potassium. IPI Research Topics No. 4. Bern. 5-48.

RAHMAN, B., 2012. Response of rice to an Integrated Nutrient Management treatment in soils collected from the long term fertility experiment. International Journal of Farm Sciences. 2. (1) 105-110.

SARKADI J., NÉMETH T. \& KÁDÁR I., 1986. A talaj könnyen oldható tápanyagtartalmának heterogenitása. Agrokémia és Talajtan. 35. (3-4) 295-306.

SÁRDI, K., 2001. A P-lekötődés és -szolgáltatás tanulmányozása tenyészedény kísérletben, tartamkísérletek talajain. Agrokémia és Talajtan. 50. (3-4) 226-246.

SÁRDI, K. \& CSATHÓ, P., 2002. Studies on the Phosphorus Retention of Different Soil Types in a Pot Experiment with Perennial Ryegrass. Hungarian Contributors to the $17^{\text {th }}$ International Congress of Soil Science. Agrokémia és Talajtan. 51. (1-2) 177184.

SÁRDI, K. \& CSATHÓ, P., 2010. Phosphorus turnover characteristics of soils: comparison of pot experiment results and modelling by stepwise regression analyses. Agrokémia és Talajtan. 59. (1) 85-92.

SÁrdi, K., Csathó, P., SisÁK, I., Osztoics E. \& BALÁzsy, Á., 2009. Effects of Freshly Applied and Residual Phosphorus on the P Status of Two Different Soils. Proceedings of the $14^{\text {th }}$ World Fertilizer Congress (Eds.: EICHLER-LOBERMANN, B.S. et al.,) 635-642. CIEC Editorial Board. Braunschweig.

SÁRDI, K., BALÁZSY, Á. \& SALAMON, B., 2012. Interrlations in Phosphorus and Potassium Accumulation Characteristics of Plants Grown in Different Soil Types. Communications in Soil Sci. and Plant Analyis. 43. 324-333.

Érkezett: 2015. február 16. 


\title{
Phosphorus dynamics in the soils of long-term field experiments
}

\author{
K. SÁRDI \\ Georgikon Faculty, University of Pannonia, Keszthely
}

\begin{abstract}
Summary
It is well-known fact that the problems involved in the application of phosphorus play an outstanding role in nutrient management, as this macroelement may not only increase the plant-available P content in the soil but may also result in environmental risks above a certain critical concentration. To achieve environmentally sound nutrient management, efficiency needs to be improved through the increased recovery of P fertilizers and the reduction of losses causing pollution.

In the present work, pot experiments and laboratory incubations were carried out on soils from long-term phosphorus fertilization experiments in order to study the quantitative aspects of phosphorus dynamics, and the phosphorus retention and phosphorussupplying capacity of various soil types. A further aim was to investigate the carry-over effects of mineral phosphorus fertilization and changes in solubility. The present paper discusses the results obtained for an Eutric Cambisol from Keszthely and a Stagnic Luvisol from Szentgyörgyvölgy.

As the result of 10 years (1963-1973) of intensive fertilisation with increasing doses of phosphorus, three $\mathrm{P}$ nutrient levels $\left(\mathrm{P}_{0}, \mathrm{P}_{1}\right.$ and $\left.\mathrm{P}_{2}\right)$ could be detected in soil samples taken from selected plots 30 years after fertilisation was discontinued. It was established that the residual effect of intensive $\mathrm{P}$ fertilisation could still be observed in the watersoluble, AL- and Olsen-P contents after 30 years. The results of the incubation experiments revealed that in the low temperature range favourable soil moisture conditions were beneficial for the short-term mobilisation of extractable P amounts, while higher temperature favoured the immobilisation of these forms.
\end{abstract}

Table 1. Major parameters of the experimental soils. (1) Long-term P level. Note: Soil $\mathrm{P}$ and $\mathrm{K}$ contents are given in terms of $\mathrm{P}_{2} \mathrm{O}_{5}$ and $\mathrm{K}_{2} \mathrm{O}$.

Table 2. Relationship between the $\mathrm{P}$ contents determined in the different extracts, after 2 and 60 days of incubation. (1) Extractants. (2) Incubation period, day. (3) Equation. (A) and (B) Incubation temperature, ${ }^{\circ} \mathrm{C}$. a) Water soluble P - Olsen-P, b) Water soluble P - AL-P. Note: Water-soluble P (MuRPHY \& Riley, 1962); Olsen-P (OLSEN \& SOMMERS, 1982); AL-P (EGNER et al., 1960).

Table 3. Changes in the available $\mathrm{P}$ content of Keszthely soil (Eutric cambisol) in response to incubation at the $\mathrm{P}_{0}, \mathrm{P}_{1}$ and $\mathrm{P}_{2}$ levels $\left(\mathrm{mg} \cdot \mathrm{kg}^{-1}\right)$. (1) Extractants. (2) Incubation temperature, ${ }^{\circ} \mathrm{C}$. (3) Incubation period, day. $\mathrm{LSD}_{5 \%}$. (A) Control. (B-D) P rates, $\mathrm{mg} \cdot \mathrm{kg}^{-1}$. a) Water soluble P. Note: $\mathrm{P}$ contents estimated from the ratio of the values recorded at $40^{\circ} \mathrm{C}$ on the $60^{\text {th }}$ and $2^{\text {nd }}$ days at the $\mathrm{P}_{0}$ and $\mathrm{P}_{1}$ levels.

Table 4. Average phosphorus recovery (\%) of freshly added $\mathrm{P}$ in the experimental soils. (1) Experimental locations. (2) Long-term P level. (3) Incubation temperature, ${ }^{\circ} \mathrm{C}$. (4) Incubation period, days.

Table 5. Relationship between plant $\mathrm{P}$ uptake and available $\mathrm{P}$ content measured in the two extract $(\mathrm{n}=60)$. (1) Soil. (2) P uptake - AL-P. (3) P uptake - Olsen-P. 